\title{
Mediasi Konflik untuk Hutan Tanaman Industri (HTI) di Indonesia Status dan Prospek
}

\author{
Yusuf Bahtimi Samsudin ${ }^{1}$ dan Romain Pirard² \\ 1 Michigan State University, 2 Center for International Forestry Research (CIFOR)
}

\section{Pesan Kunci}

- Mediasi merupakan mekanisme resolusi konflik yang muncul di berbagai negara yang terdapat banyak konflik terkait dengan lahan dan hutan tanaman industri, namun penerapannya di lapangan belum menunjukkan hasil yang memuaskan

- Mediasi dapat dilihat sebagai bagian dari transformasi konflik karena bertujuan untuk mencapai solusi jangka panjang yang diterima oleh semua pihak

- Terdapat banyak pendekatan mediasi di Indonesia, sangat bergantung pada hubungannya dengan proses hukum dan status mediator, yang kemudian membuka kesempatan bagi mediasi di bawah payung proses pengadilan dengan mediator bersertifikat

- Munculnya mediasi yang diakui oleh Kementerian Kehutanan Indonesia erat kaitannya pada pengakuan adanya "konflik" dalam domain (ranah) hutan yang berseberangan istilah dengan "pelanggaran hukum" dalam kehutanan

- Penelitian di Provinsi Jambi, Sumatera, dengan kasus yang dianggap sukses oleh para pihak menunjukkan sejumlah tantangan dalam penerapan mediasi konflik yang rapuh. Ada kemungkinan bahwa hasilnya tidak berkelanjutan ketika tidak memenuhi perannya sebagai sarana "resolusi konflik"

- Berbagai keterbatasan yang dihadapi dalam mediasi seharusnya tidak mencegah para pihak di Indonesia untuk mempromosikan mediasi konflik sebagai pendekatan alternatif dalam resolusi konflik, membangun kerangka hukum, mengembangkan pengalaman dan jaringan mediator secara dinamis

\section{Latar Belakang}

Hutan tanaman industri diperkirakan akan berkembang secara dramatis untuk memenuhi tuntutan kebutuhan akan serat, pangan dan energi di masa depan. Dalam dekade terakhir hingga tahun 2010, perluasan hutan tanaman terjadi secara besar-besaran hingga mencapai lima juta hektar per tahun secara global (FAO 2010).

Data dari Kementerian Kehutanan Indonesia menunjukkan bahwa terdapat 10 juta hektar luas wilayah yang telah mendapat izin pemanfaatan HTI (Kementerian Kehutanan 2014), namun analisis Forest Watch Indonesia (FWI) (2014) menunjukkan bahwa HTI yang telah dimanfaatkan hanya seluas 5,7 juta hektar. Salah satu penyebab tidak optimalnya pencapaian penanaman adalah tumpang tindih klaim kepemilikan lahan dengan masyarakat lokal. Usaha optimalisasi pemanfaatan 10 juta hektar yang telah mendapat izin HTI diperkirakan dapat meningkatkan jumlah konflik.

Oleh karena itu resolusi konflik diperlukan karena potensi munculnya kekerasan, ketidakadilan, kerugian ekonomi, keterbatasan pembangunan pada tingkat lokal, dan merosotnya kredibilitas negara dalam hal keadilan dan kapasitas penegakan hukum. Sepanjang tahun 2013 tercatat 369 konflik agraria di Indonesia, yang melibatkan lahan seluas sekitar 1,2 juta hektar, sementara kejadian di sektor kehutanan sebanyak 31 konflik dengan jumlah luas lahan kira-kira 0,5 juta hektar (konflik di sektor kehutanan yang terluas) (KPA 2013).

Namun data tersebut harus ditafsirkan secara hati-hati, karena beberapa data dari berbagai sumber menunjukkan hasil yang berbeda. Sebagai contoh Konsorsium Pembaruan Agraria (KPA) mencatat sepanjang tahun 2012 terdapat 163 konflik agraria (KPA 2012). Sementara Siagian (2012) dalam Komnas HAM (2012) mencatat 738 kasus konflik lahan terkait sumber daya alam. Saat ini organisasi HuMa sedang mengembangkan sistem identifikasi konflik agraria dengan mengumpulkan data primer dan sekunder melalui jaringan kerja sama HuMa dan Pendamping Hukum Rakyat (PHR) di berbagai tempat di Indonesia (Andiko Mancayo, komunikasi pribadi,

9 April 2014).

Artikel ini mengkaji satu pendekatan dalam menyelesaikan konflik yang terkait dengan hutan tanaman industri di Indonesia, dengan fokus mediasi konflik sebagai pendekatan yang banyak dibicarakan sekarang (misalnya, Dhiaulhaq, dkk. 2015). Tulisan 
ini bertujuan untuk memberikan informasi status terkini tentang penerapan mediasi di Indonesia, karena keragaman bentuk penerapan mediasi dan sifat mediasi yang fleksibel yang tengah berkembang sesuai dengan situasi di lapangan. Analisis ini diharapkan dapat berkontribusi pada tataran debat mengenai prospek dan pilihan pendekatan-pendekatan dari pengelolaan konflik, disertai klarifikasi dari cakupan bidang yang termasuk di dalamnya.

Penelitian ini didasarkan pada kajian berbagai pustaka mengenai mediasi, dan wawancara mendalam dengan pemain utama mediasi di Indonesia, dari badan publik (misalnya, Mahkamah Agung) hingga jaringan organisasi profesional (misalnya, Dewan Kehutanan Nasional), serta beberapa organisasi nonpemerintah. Penelitian ini juga menyajikan kasus studi sebagai gambaran kasus mediasi konflik yang sukses sebagai solusi resolusi konflik.

\section{Ruang Lingkup Permasalahan}

\section{Konflik vs Sengketa}

Konflik diartikan sebagai "Ketidaksepahaman antarpihak yang menggiring pada ketegangan dalam, dan antara orang-orang" (Vestegaard, dkk. 2011). Kata konflik dinilai sebagai lawan kata dari 'kerja sama' dan 'perdamaian' dan sering dikonotasikan negatif dan diasosiasikan dengan kekerasan atau hal yang mengarah pada kekerasan. Meskipun demikian, konflik tidak harus selalu berbentuk kekerasan

Peraturan Badan Pertanahan Nasional (BPN) Nomor 3 tahun 2011 secara jelas menyebutkan bahwa terdapat perbedaan antara konflik dan sengketa. Sementara itu dalam konteks kehutanan, UU Nomor 41 tahun 1999 menyebutkan perselisihan yang menyangkut kehutanan sebagai "sengketa" tanpa memberikan penjabaran mengenai kata tersebut, dan tidak ditemukan penyebutan kata "konflik". Konflik biasa disebutkan sebagai perselisihan dalam skala yang lebih luas dan mencakup perselisihan yang bersifat terpendam (latent) dan mengemuka (manifest), meskipun sebagian para ahli berpendapat bahwa tidak ada perbedaan yang cukup berarti, di luar faktor bahwa konflik lebih sering digunakan pada konteks ilmu sosial dan politik, sedangkan sengketa digunakan pada konteks ilmu hukum (Rahmadi, 2010). Tulisan ini akan menggunakan kedua istilah bersama-sama.

\section{Pendekatan-Pendekatan Pengelolaan konflik}

Pengelolaan konflik dijelaskan sebagai berikutnya: bentuk upaya yang ditempuh bisa bermacam-macam, mulai dari yang sangat sederhana sampai ke tingkat pengadilan dengan menempuh jalur hukum (Fisher, dkk., 2001 dalam Wulan, dkk., 2004). Banyak pilihan yang dapat diambil dalam melakukan pengelolaan konflik, Moore (2003) membagi beberapa opsi pengelolaan konflik menjadi empat kategori berdasarkan keterlibatan pihak yang bersengketa/ berkonflik dalam suatu upaya resolusi, yaitu pengambilan keputusan secara informal oleh para pihak yang bersengketa (informal decision-making by conflict parties), pengambilan keputusan oleh pihak ketiga secara informal (informal third-party decision making), pengambilan keputusan oleh pihak ketiga yang memiliki kekuatan otoritatif (legal (public) authoritative third-party decision making), dan pengambilan keputusan yang sah secara hukum namun bersifat "memaksa" (extralegal coerced decisionmaking) (Gambar 1).

Botes (2003) mencatat bahwa pengertian transformasi konflik berbeda dengan resolusi konflik karena transformasi diartikan sebagai proses penciptaan kerja sama jangka panjang antarpihak dan proses untuk mengatasi interaksi negatif antarpihak. Meskipun demikian, beberapa ahli menempatkan transformasi konflik sebagai rangkaian kesatuan pengelolaan konflik dengan proses sebagai berikut: penyelesaian konflik (conflict settlement), pengelolaan konflik (conflict management), resolusi konflik (conflict resolution), dan transformasi konflik (conflict transformation).

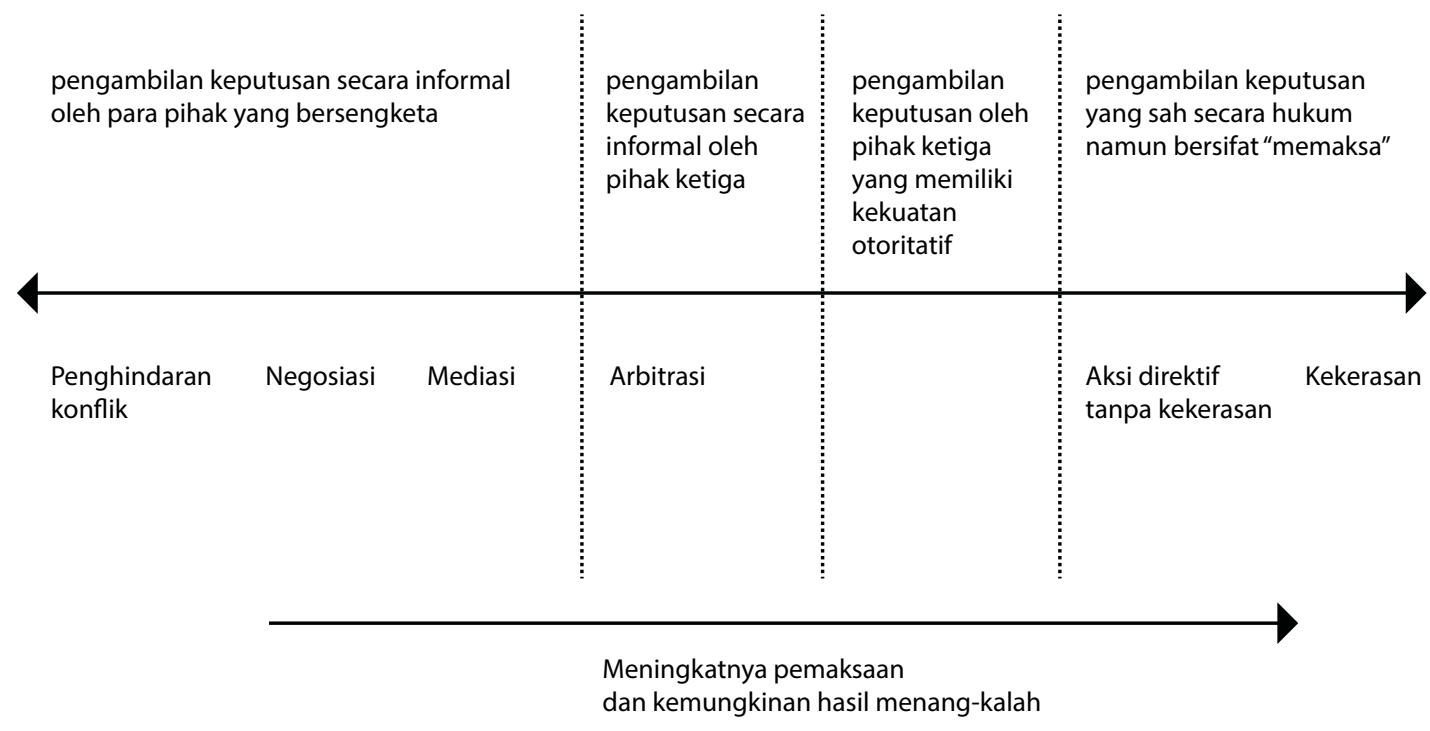

Gambar 1. Hubungan antara beberapa alternatif pengelolaan konflik dengan tingkat keterlibatan para-pihak 


\section{Kotak 1. Definisi mediasi menurut beberapa sumber:}

Yasmi, dkk. (2010) "Mediation - a form of third party intervention in which a mediator facilitates conflict management but he/she does not have the authority to impose a solution".

Soematrono (2006) "Mediasi adalah upaya menyelesaikan konflik dengan melibatkan pihak ketiga yang netral, yang tidak memiliki kewenangan mengambil keputusan yang membantu pihak-pihakyang bersengketa mencapai penyelesaian (solusi) yang diterima oleh kedua belah pihak".

Rahmadi (2010) "Mediasi adalah suatu proses penyelesaian sengketa antara dua pihak atau lebih melalui perundingan atau cara mufakat dengan bantuan pihak netral yang tidak memiliki kewenangan memutus".

\section{Kemunculan Mediasi Konflik Sebagai Pendekatan Penyelesaian Konflik di Indonesia}

\section{Definisi dan Karakteristik Mediasi Ditinjau dari Pustaka dan Peraturan Hukum}

Usaha pengelolaan konflik kehutanan di Indonesia yang didorong oleh Dewan Kehutanan Nasional (DKN) dibagi menjadi dua jenis. Pertama adalah interest-based conflict resolution, dimana usaha resolusi konflik lebih mendekat kepada penggalian akar masalah dan penyelesaian masalah secara terstruktur, seperti pengaturan kembali kebijakan-kebijakan yang melatar belakangi atau terkait erat dengan konflik. Kedua, adalah objective-based conflict resolution dimana usaha resolusi konflik berupa pendekatan kepada tujuan dan keinginan dari pihak yang bersengketa/ berkonflik, dan berusaha mencari solusi tengah. Mediasi merupakan bagian dari objective-based conflict resolution (Martua Sirait, komunikasi pribadi, 23 Mei 2014).

Kesalahpahaman pengertian fasilitator sebagai mediator sering terjadi (Ahmad Zazali, komunikasi pribadi, 3 Juni 2014). Mediator juga dapat berasal dari lembaga yang mempunyai kekuatan untuk memutus, namun tidak menggunakan kewenangannya untuk memutus (Takdir Rahmadi, komunikasi pribadi, 8 Mei 2014). Karena itu dapat dipahami secara umum bahwa mediasi merupakan solusi pengelolaan sengketa/konflik yang dijembatani oleh pihak ketiga yang tidak mempunyai otoritas, atau badan yang mempunyai otoritas namun tidak menggunakan kekuatan otoritasnya untuk memaksa jalannya mediasi.

Sebelum memasuki deskripsi variasi tipe mediasi di Indonesia, kami mengusulkan diagram analisis Strengths (Kekuatan),

Weaknesses (Kelemahan), Opportunities (Peluang), dan Threats (Ancaman) (SWOT) (Gambar 2). Analisis ini berdasarkan dari sumber utama oleh ahli dari Mahkamah Agung (Rahmadi, 2010), serta dari wawancara kunci dengan ahli dan praktisi mediasi. Hasil analisis dirangkum dalam Gambar 2 berikut:

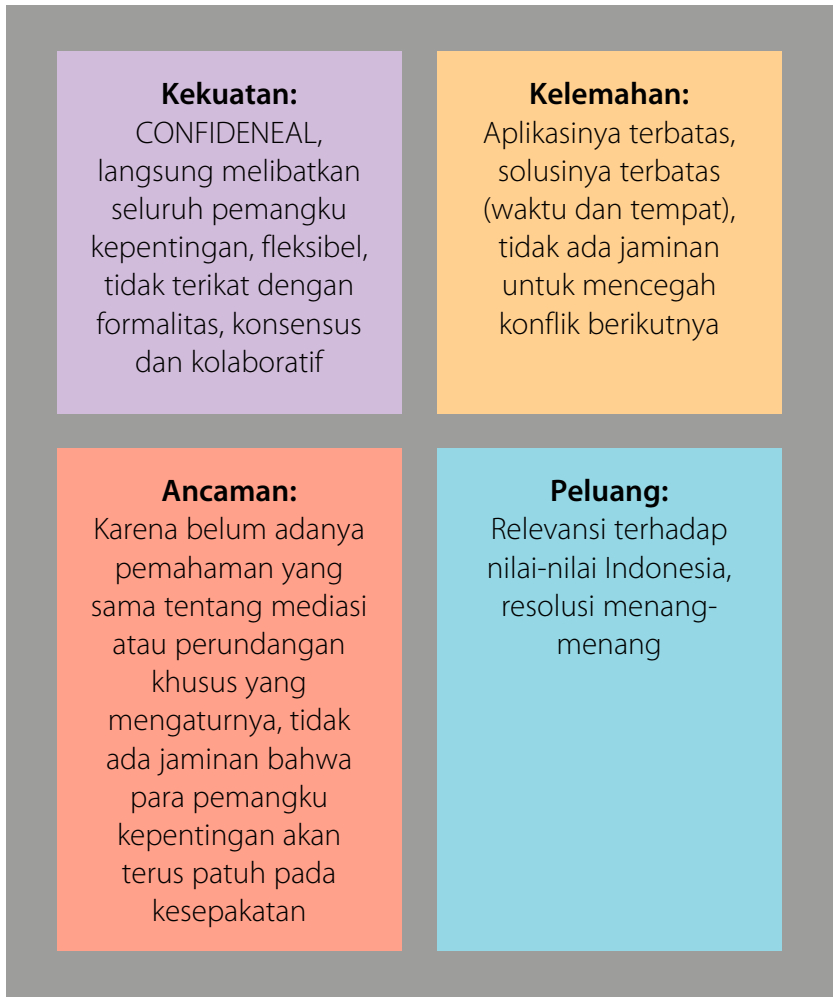

\section{Gambar 2. Analisis SWOT mengenai aplikasi mediasi konflik di Indonesia}

Sumber: Rahmadi (2010) dan sejumlah wawancara

\section{Mediasi dalam Kerangka Hukum di Indonesia: di dalam/luar pengadilan}

Pelaksanaan mediasi di Indonesia terbagi menjadi dua, yaitu mediasi di dalam dan di luar pengadilan. Penyebutan mediasi di luar pengadilan dalam konteks kehutanan dapat ditemui dalam UU Nomor 41 tahun 1999 tentang Kehutanan pasal 75 ayat 1,2, dan 3, sedangkan mediasi di dalam pengadilan berada dalam kerangka Peraturan Mahkamah Agung (PERMA) Nomor 1 tahun 2008. Kesepakatan mediasi di luar pengadilan dapat didaftarkan ke pengadilan untuk memperoleh legitimasi yang sama kuatnya dengan hasil mediasi di dalam pengadilan, dengan cara mengajukan 'gugatan sementara' (Takdir Rahmadi, komunikasi pribadi, 8 Mei 2014).

Meskipun UU 41 tahun 1999 menyebutkan bahwa sengketa kehutanan dapat diselesaikan di luar pengadilan, hal tersebut tidak menyebutkan mediasi secara khusus, dan klaim terhadap kawasan hutan masih dinilai sebagai kegiatan yang melanggar hukum (pidana). Pasal 75 ayat 1 dalam undang-undang ini memberikan batasan bahwa penyelesaian sengketa di luar pengadilan tidak dapat dilakukan pada ranah perkara pidana. Pasal 50 ayat 3 undang-undang yang sama secara literal melarang perambahan dan 'pemanfaatan' wilayah hutan, dan pelanggaran terhadap ketentuan ini dikategorikan sebagai pelanggaran hukum pidana.

Dalam konteks Presiden dan Pemerintahan baru pada 2014 yang menaruh perhatian serius pada penguatan dan pengakuan hak-hak masyarakat secara umum dan masyarakat adat khususnya dan 
Tabel 1. Perbedaan antara mediasi di dalam dan di luar pengadilan dalam masalah kehutanan

\begin{tabular}{ll}
\hline Mediasi di dalam pengadilan & Mediasi di luar pengadilan \\
\hline $\begin{array}{l}\text { Dibatasi oleh waktu (maksimum waktu mediasi 40 hari dan } \\
\text { dapat diperpanjang maksimum 14 hari) }\end{array}$ & $\begin{array}{l}\text { Tidak terbatas waktu (beberapa kasus berlangsung hingga } \\
\text { hitungan tahun) }\end{array}$ \\
\hline $\begin{array}{l}\text { Mediasi merupakan kewajiban untuk kasus perdata } \\
\text { (termasuk kasus kehutanan) }\end{array}$ & $\begin{array}{l}\text { Mediasi merupakan opsi yang bersifat sukarela; hanya dapat } \\
\text { dijalankan pada kasus perdata }\end{array}$ \\
\hline $\begin{array}{l}\text { Mediator dapat dipilih oleh pihak yang bersengketa atau } \\
\text { dipilih oleh hakim dalam mekanisme pengadilan }\end{array}$ & $\begin{array}{l}\text { Pihak yang bersengketa dapat meminta organisasi tertentu untuk } \\
\text { memediasi kedua belah pihak, atau mediasi dapat difasilitasi oleh } \\
\text { pihak ketiga (misalnya, Kementerian Kehutanan, DKN) }\end{array}$ \\
\hline Diatur di dalam PERMA 1 tahun 2008 & $\begin{array}{l}\text { Disebutkan sebagai pilihan alternatif penyelesaian konflik/ } \\
\text { sengketa dalam UU 41 tahun 1999 tentang Kehutanan }\end{array}$ \\
\hline Hasil kesepakatan mempunyai kekuatan pengadilan & $\begin{array}{l}\text { Pihak yang bersepakat dapat mengajukan hasil kesepakatan untuk } \\
\text { diperkuat di pengadilan dengan mengajukan "gugatan pura-pura" }\end{array}$
\end{tabular}

Sumber: Penulis

dukungan terhadap usaha lokal serta hutan kemasyarakatan, mediasi diharapkan dapat dipromosikan sebagai alternatif pengelolaan konflik yang secara resmi disertakan dalam proses serta produk hukum.

PERMA Nomor 1 tahun 2008 disusun untuk mengakomodasi kasus perdata konflik, sembari menunggu Peraturan UndangUndang. Mediasi juga hanya dapat dilaksanakan pada kasus perdata, di luar maupun di dalam pengadilan, sedangkan kasus pidana tidak dapat diselesaikan dengan mediasi (Mahkamah Agung Republik Indonesia, 2008).

Proses sengketa perdata yang dilakukan mewajibkan para pihak yang bersengketa melakukan mediasi dengan fasilitasi dari mediator yang telah mendapat sertifikat dari MA. Sifat sukarela proses mediasi juga harus berlaku dalam mediasi di dalam pengadilan, meskipun kewajiban untuk melaksanakan mediasi dijatuhkan oleh pengadilan. Namun demikian kesepakatan dalam proses pencapaian konsensus dalam proses mediasi tidak boleh bersifat 'memaksa'.

\section{Upaya Mediasi Konflik di Indonesia, serta Peran Kunci Mediator}

Belum adanya peraturan khusus mediasi di luar pengadilan dapat menjadi kelebihan bagi proses mediasi karena dalam pelaksanaannya menjadi bersifat fleksibel dan dapat disesuaikan dengan kondisi di lapangan (Rahmadi, 2010). Meskipun demikian, hal ini juga menyulitkan para pihak, utamanya mediator, karena tidak adanya acuan mengenai kode etik dan proses umum mediasi (Ahmad Zazali, komunikasi pribadi, 3 Juni 2014).

Perbedaan fungsi mediator dan fasilitator sering tidak dipahami dengan benar, terutama dalam hal norma dan sifat kerja masingmasing. Dalam hal ini sikap mediator haruslah benar-benar netral. Pembeda utama antara mediasi dan fasilitasi adalah dalam hal penunjukkan mediator. Mediator harus ditunjuk, atau memperoleh mandat, yang disepakati oleh para pihak yang bersengketa sebagai penengah atau jembatan kedua belah pihak (atau lebih) aktor utama sengketa (Ahmad Zazali, komunikasi pribadi, 3 Juni 2014). Proses pendorongan mediasi di Indonesia melahirkan beberapa organisasi payung mediator di Indonesia, misalnya Impartial Mediator Network (IMN). Sementara itu fasilitasi lebih bersifat pada proses pendampingan masyarakat. Kedua fungsi yang berbeda ini masih banyak disalahpahami oleh beberapa pihak, utamanya kalangan LSM (Lembaga Swadaya Masyarakat) (lbid).

\section{Studi Kasus di Jambi, Sumatera ${ }^{3}$}

Analisis mengenai status dan arah mediasi di Indonesia dilakukan berdasarkan studi kasus dari Provinsi Jambi, dimana penerapan mediasi telah berlangsung selama dekade terakhir. Walaupun kasus yang ditangani dapat dikatakan sukses dalam mencapai kesepakatan antara para pihak, suasana ketegangan konflik masih dirasakan cukup kuat. Oleh karena itu, proses wawancara di lapangan masih dirasakan agak sulit dan diarahkan kepada pengurus Koperasi Senyerang Bertuah dan Lurah Senyerang, dan beberapa anggota masyarakat yang bersedia.

\section{Latar Belakang Terjadinya Konflik}

Tipologi konflik di Senyerang berupa klaim masyarakat Senyerang atas hak tanah adat pada konsesi HTI PT. Wira Karya Sakti (WKS) di bawah Sinarmas Forestry (SMF) yang telah ditanami akasia yang mulai memasuki daur ketiga pada saat konflik memanas. Klaim oleh masyarakat dimulai sejak 2001 berupa pengajuan protes kepada pemerintah setempat. Konflik juga mengalami pasang surut beberapa kali, dan memasuki puncaknya setelah tahun 2008, dan selesai tahun 2013 (Gambar 3).

Sengketa dilatarbelakangi rekomendasi oleh Pemerintah Kabupaten Tanjung Jabung Barat pada tahun 2001 mengenai lahan dengan status APL menjadi kawasan Hutan Produksi (HP).

3 Studi kasus yang dilaporkan di InfoBrief ini bisa dibandingkan dengan studi kasus mediasi untuk HTI di Provinsi Riau di Sumatera (Dhiaulhaq, dkk. 2014) 


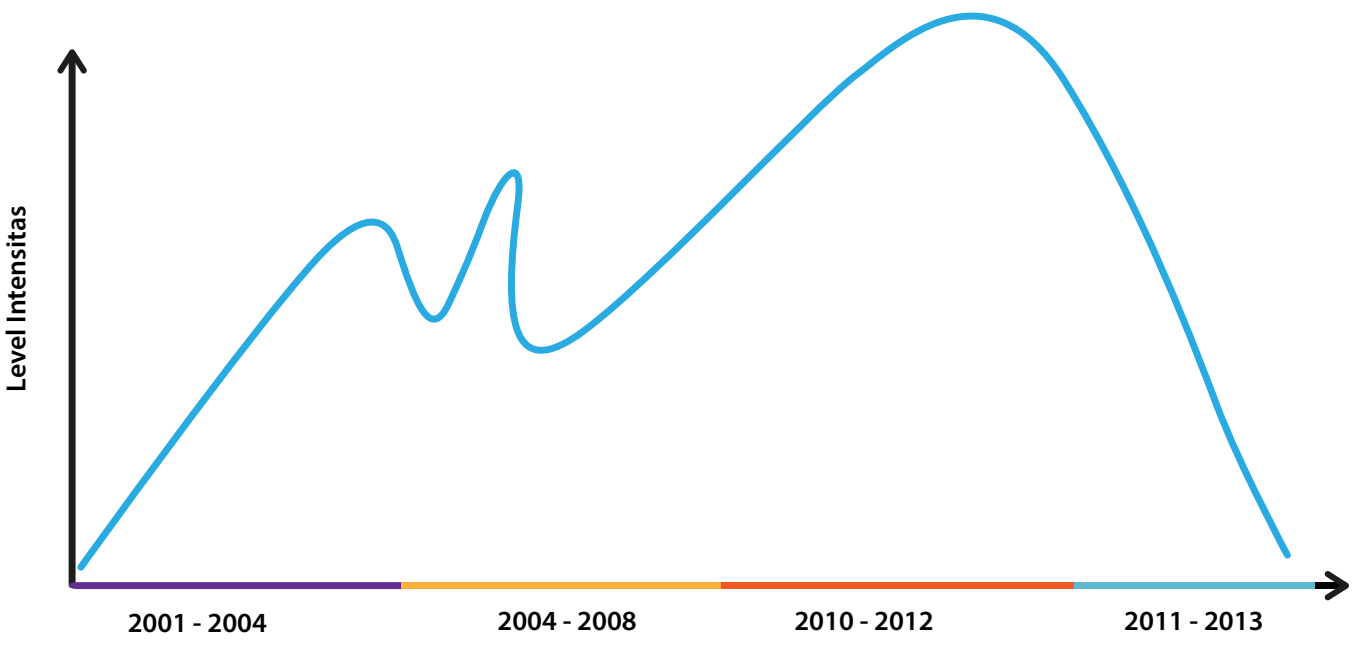

\begin{tabular}{|c|c|c|c|}
\hline $\begin{array}{l}\text { Fase Laten } \\
\text { - Keluarnya Perda No } \\
52 \text { tahun } 2001 \text { dan SK } \\
\text { Menhut No. 64/Kpts- } \\
\text { II/2001 atas pemberian } \\
\text { izin HTI kepada PT. WKS } \\
\text { - Penolakan dari } \\
\text { masyarakat, protes } \\
\text { kepada Pemerintah } \\
\text { Daerah dilakukan }\end{array}$ & $\begin{array}{l}\text { Eskalasi Konflik } \\
\text { - Protes dan } \\
\text { penolakan dari } \\
\text { masyarakat terus } \\
\text { berlangsung } \\
\text { - Sempat terjadi } \\
\text { penurunan suhu } \\
\text { konflik pada tahun } \\
2004 \text { dan 2008, } \\
\text { namun kesepakatan } \\
\text { akhirnya gagal }\end{array}$ & $\begin{array}{l}\text { Puncak Konflik } \\
\text { - } \quad \text { Terjadi pemblokiran } \\
\text { jalan dilakukan oleh } \\
\text { pihak masyarakat } \\
\text { - Pendudukan lahan } \\
\text { oleh pihak masyarakat } \\
\text { - Pemblokiran } \\
\text { jalur sungai yang } \\
\text { merupakan jalur } \\
\text { angkut perusahaan } \\
\text { - Jatuhnya korban } \\
\text { Ahmad Adam dari } \\
\text { pihak masyarakat }\end{array}$ & $\begin{array}{l}\text { Tahap Penyelesaian } \\
\text { - Ketegangan masih } \\
\text { sering berlangsung } \\
\text { - Semua pihak } \\
\text { meminta DKN } \\
\text { menjadi mediator } \\
\text { hingga } 2013 \\
\text { - Mediasi dilanjutkan } \\
\text { oleh TFT hingga } \\
\text { kesepakatan tercapai }\end{array}$ \\
\hline
\end{tabular}

\section{Gambar 3. Alur waktu dan kejadian konflik di Kelurahan Senyerang, Kabupaten Tanjung Jabung Barat, Provinsi Jambi}

Sumber: Sirait, 2012; Kompas 31 Maret 2012; Metro Jambi 1 Juni 2012; Usman, 2012

Respon atas rekomendasi tersebut kemudian dilanjutkan dengan dikeluarkannya keputusan Menteri Kehutanan No. 64/Kpts-II/2001 untuk luas areal Hak Pengusahaan Hutan Tanaman Industri (HPHTI) seluas 191.130 hektar, perubahan pertama setelah SK definitif dari Kementerian Kehutanan No. 774/Kpts-II/1996 tertanggal 25 November 1996 untuk wilayah areal 78.240 hektar. Areal yang disebutkan dalam keputusan tersebut kemudian diklaim juga oleh masyarakat Senyerang sebagai tanah adat yang berada pada kanal 1-19, berdasarkan pada Surat Keterangan Penghulu Senyerang tahun 1927, dan Surat Keterangan Demang Kuala Tungkal tahun 1928 (Sirait, dkk., 2012).

4 Pada saat SK No. 64/Kpts-11/2001 diterbitkan, area yang disengketakan oleh masyarakat Senyerang diakui oleh masyarakat masih berstatus Areal Penggunaan Lain (APL) dan status perubahan menjadi Hutan Produksi (HP) baru diterbitkan pada tahun 2004. Tahun 2004 juga terdapat dua kali adendum setelah keputusan tahun 2001, dimana SK Menteri Kehutanan No. 228/Menhut-II/2004 memperluas areal konsesi menjadi 233.251 hektar, dan adendum selanjutnya menambah luas areal menjadi 293.812 hektar dengan SK Menteri Kehutanan No. 346/Menhut-II/2004

\section{Proses Pengelolaan konflik}

Proses usaha pengelolaan sengketa/konflik di Kelurahan Senyerang telah dilakukan sejak 2001. Upaya penyelesaian dalam bentuk protes masyarakat dilakukan dengan pengiriman protes ke pemerintah daerah, namun pada saat itu tidak ada tanggapan yang memuaskan bagi masyarakat. Upaya penyelesaian melalui jalan negosiasi tercatat beberapa kali dilakukan (Kompas, 31 Maret 2012; Sirait, dkk., 2012). Gelombang protes dari masyarakat sedikit mereda tahun 2004 karena permintaan masyarakat dikabulkan oleh perusahaan untuk pembangunan tempat ibadah, dan perekrutan masyarakat Senyerang menjadi karyawan PT. WKS (Kompas, 31 Maret 2012). Kesepakatan antara PT. WKS dan Persatuan Petani Jambi (PPJ) sebagai pendamping perwakilan masyarakat Senyerang sempat dicapai pada tahun 2008, namun kemudian kesepakatan ini dibatalkan oleh pihak PPJ yang merasa kesepakatan ini tidak memberikan kesejahteraan yang merata bagi seluruh anggota PPJ Senyerang (Sirait, dkk., 2012). 
Dewan Kehutanan Nasional (DKN) juga tercatat berperan dalam mendorong pelaksanaan mediasi di Kelurahan Senyerang pada periode 2011-2013 berdasarkan permintaan dari pihak masyarakat, Kementerian Kehutanan, dan perusahaan. Hasil akhir dari mediasi berupa penyerahan rekomendasi kepada Kementerian Kehutanan hingga memunculkan ide awal kemitraan sebagai upaya penyelesaikan konflik (Martua Sirait, komunikasi pribadi, 23 Mei 2014). Selain itu, Pemerintah Provinsi juga berperan melalui SK. Gubernur Jambi sebagai dasar hukum pembentukan tim terpadu penyelesaian konflik di Senyerang. Tim ini menghasilkan rekomendasi kepada Kemenhut untuk mengeluarkan kebijakan kemitraan dengan komposisi tanaman 90\% karet dan 10\% Akasia (Sirait, dkk., 2012).

Ketidakpuasan masih ditemukan dari beberapa pihak atas hasil rekomendasi dari mediasi sebelumnya, sehingga Kementerian Kehutanan mengeluarkan mandat kepada The Forest Trust (TFT) untuk melanjutkan proses mediasi. Sikap awal masyarakat ketika TFT melakukan pengkajian awal menunjukkan keengganan, namun pada keputusan rapat akbar selanjutnya masyarakat meminta kepada TFT untuk menjembatani mediasi. DKN mengambil posisi sebagai tim pemantau independen atas proses dan komitmen mediasi yang berlangsung (Martua Sirait, komunikasi pribadi, 23 Mei 2014).

\section{Dinamika Tahap Akhir Penyelesaian dengan Mediasi}

Para aktor pendukung yang berperan dalam proses mediasi kasus ini adalah Dinas Kehutanan Provinsi Jambi, Dinas Kehutanan Kabupaten Tanjung Jabung Barat, PPJ, DKN, TFT, Walhi dengan aktor utama masyarakat dan perusahaan. Mediasi digunakan sebagai langkah penyelesaian konflik setelah mekanisme lain, seperti negosiasi, tidak berhasil.

Saat konflik berlangsung, pertemuan internal masyarakat berlangsung rutin setiap 2-3 hari sekali sebagai penjaringan aspirasi masyarakat, yang kemudian diteruskan ke meja perundingan, baik dalam proses negosiasi maupun mediasi. Keputusan untuk menempuh mediasi muncul karena kejenuhan akan konflik yang berlangsung dan inisiatif dari masyarakat untuk menyudahinya.

Proses mediasi yang dilakukan oleh TFT diawali dengan tim TFT yang turun ke lapangan untuk melakukan penjajakan keinginan masing-masing pihak yang bersengketa (Berdy Stevens, komunikasi pribadi, 12 Juli 2014). Pihak masyarakat menyampaikan keinginan untuk berdialog langsung dengan keluarga Eka Tjipta sebagai pemilik perusahaan sebagai bagian dari proses pencapaian konsensus, Hal ini disetujui oleh pihak Eka Tjipta. Hingga tahap ini, masyarakat bertindak sendiri tanpa diwakili oleh pihak PPJ, dengan cara mengirimkan delegasi yang beranggotakan 2-5 orang dari Senyerang ke Jakarta. Delegasi ini melakukan sejumlah pertemuan dengan pihak Kementerian Kehutanan dan SMF dan dijembatani oleh TFT.

Pertemuan yang dilakukan di Jakarta selalu didampingi dan dikawal oleh Dinas Kehutanan Kabupaten Tanjung Jabung Barat dan pihak dari Dinas Kehutanan Pemerintah Provinsi Jambi selaku Pemerintah Daerah. Hasil akhir upaya mediasi adalah kesepakatan (MoU) pada 5 Juli 2013 di Kementerian Kehutanan yang penandatanganannya dipimpin oleh Dirjen BUK Kementerian Kehutanan, dan para pihak lain seperti Pemerintah Kabupaten dan Pemerintah Provinsi. Sebelumnya hasil kesepakatan ini telah ditandatangani oleh 2002 Kepala Keluarga masyarakat petani di Kelurahan Senyerang.

\section{Konsensus Akhir Hasil Mediasi}

Hasil mediasi berupa rincian kesepakatan menyebutkan bahwa areal seluas empat ribu hektar yang disengketakan adalah untuk penanaman karet dan akasia. Pengadaan bibit karet disediakan dari pusat pembenihan karet yang berada di Medan yang ditangani oleh Dinas Perkebunan Kabupaten Tanjung Jabung Barat (Haidir, komunikasi pribadi, 8 Juli 2014). Selain itu juga disepakati bahwa akan diadakan pelatihan bagi petani untuk penanaman karet, dan pengelolaan perkebunan akan dilaksanakan melalui koperasi masyarakat di bawah pengawasan Dinas Koperasi Kabupaten.

Hasil kesepakatan juga menyetujui pengucuran dana bantuan dari PT. WKS melalui koperasi masyarakat untuk membiayai operasional kebun karet. Dana bagi hasil juga akan dikucurkan kepada koperasi setiap tahunnya pada periode 2014-2035. Pemantauan rutin dilakukan oleh pihak TFT, yang mencakup implementasi konsensus, sementara pemantauan eksternal akan dilakukan oleh pihak DKN yang diketuai oleh Martua Sirait dengan 7 orang anggota.

Semua pihak yang telah diwawancarai dan terlibat langsung dalam proses mediasi, antara lain masyarakat, perusahaan, TFT, dan pemerintah daerah, mengemukakan bahwa kunci keberhasilan dari mediasi yang telah dilaksanakan ialah adanya kemauan dari para pihak untuk menempuh mediasi, serta keinginan dari semua pihak agar konflik segera berakhir. Selain itu, peran kepemimpinan dari pihak masyarakat juga sangat menentukan dalam tercapainya konsensus. Wakil-wakil mereka mampu menampung aspirasi seluruh masyarakat, konsisten dalam pendirian, sekaligus mempunyai keinginan yang kuat dalam menyelesaikan permasalahan sehingga memberikan pengaruh yang kuat bagi jalannya resolusi konflik.

Keterbukaan dan kemauan dari pihak perusahaan juga dinilai penting dalam tercapainya konsensus resolusi konflik. Dalam kasus ini pihak perusahaan dan keluarga Eka Tjipta Wijaya sebagai pemilik perusahaan terbuka untuk melakukan pertemuan dengan pihak masyarakat Senyerang, disertai pihak TFT sebagai mediator untuk penggodogan butir-butir dalam konsensus ${ }^{5}$. Solusi yang memenangkan semua pihak juga dinilai tercapai, dimana para pihak setuju dengan butir-butir yang dirumuskan dalam konsensus. Bentuk persetujuan dari masyarakat terhadap konsensus tidak hanya ditandatangani oleh perwakilan masyarakat, namun oleh seluruh Kepala Keluarga/di Kelurahan Senyerang.

5 Pertemuan-pertemuan terpisah dari pihak TFT sebagai mediator dengan pihak yang bersengketa tercatat beberapa kali dilakukan, sebelum dan sesudah pertemuan antara pihak masyarakat dan pihak SMF/Eka Tjipta Wijaya dalam usaha perumusan konsensus. 


\section{Kesimpulan}

Mediasi merupakan proses pengelolaan konflik yang tidak hanya bertujuan menghentikan kekerasan, seperti yang termaktub dalam pengertian resolusi konflik, namun merupakan solusi jangka panjang yang berupaya mengubah paradigma hubungan sosial sehingga muncul keharmonisan dan saling percaya antara para pihak

Mediasi menawarkan prospek cerah dalam pengelolaan konflik, karena memberikan peluang bagi peningkatan keterlibatan para pihak yang berwenang, sertifikasi para mediator, dan penerapan mediasi dalam kasus-kasus di pengadilan. Syukur dan Bagshaw (2013) juga mengatakan bahwa "penerapan mediasi dalam pengadilan di Indonesia merupakan usaha revitalisasi semangat musyawarah pada prosedur hukum ". Keterlibatan para pihak yang berwenang dalam mediasi tampak dalam kasus yang kami kaji di lapangan, yang bahkan menjadi salah satu inspirasi dalam terbentuknya Peraturan Menteri yang mendorong adanya pencapaian perjanjian berupa kemitraan pada konsensi HTI (P.39/ Menhut-II/2013).

Meskipun studi yang kami kaji terbilang sukses dalam menerapkan mediasi, terdapat beberapa keterbatasan. Antara lain sejumlah keterbatasan ini terkait dengan biaya yang mahal, memerlukan perubahan dan adaptasi sesuai dengan kondisi di lapangan, dan memakan waktu lama karena mediator harus bergantiganti. Karena itu mediasi bukan merupakan garansi keberhasilan untuk resolusi konflik. Meskipun demikian, pelaksanaannya patut didorong dilihat dari kapasitas mediasi dalam menawarkan solusi yang bersifat partisipatif dan transparan berdasarkan keterampilan dan pengalaman para mediator.

Infobrief ini menyajikan ikhtisar status mediasi di Indonesia dengan sedikit gambaran dari studi kasus yang menggambarkan titik terang prospek mediasi sebagai alat yang efektif dalam resolusi konflik. Penelitian lanjutan dalam skala sampel yang lebih besar penting untuk dilakukan guna mengidentifikasi kondisi dari kasuskasus mediasi yang beragam. Hal ini erat hubungannya dengan konteks meningkatnya konflik dalam konsesi hutan tanaman industri dimana Kementerian Lingkungan Hidup dan Kehutanan memandangnya sebagai hambatan utama dalam pengembangan sektor hutan tanaman di masa depan.

\section{Ucapan Terima Kasih}

Studi ini didukung oleh DfID melalui proyek KNOW-FOR.

Kami mengucapkan terima kasih kepada dua reviewer Dede Rohadi dan Ahmad Dhiaulhaq.

Kami mengucapkan terima kasih kepada narasumber wawancara utama, Prof. Dr. Takdir Rahmadi, SH. LL.M (Hakim Agung Mahkamah Agung Republik Indonesia), Andiko Mancayo (Direktur Eksekutif HuMA), Christian Purba (Direktur Eksekutif Forest Watch Indonesia - FWI), Wiwiek Awiati (Peneliti ICEL/Universitas Indonesia), Agung Wiyono (Group Manager \& Social Specialist, The Forest Trust TFT), Martua Sirait (Dewan Kehutanan Nasional - DKN), Ahmad Zazali (Direktur Eksekutif Impartial Mediator Network - IMN), Erik M. Tjahjono (Dinas Kehutanan Provinsi Jambi), Dri Handoyo (Dinas Kehutanan Kabupaten Tanjung Jabung Barat), serta dukungan dari para pihak yang telah membantu selama pengumpulan data di lapangan, Berdy Stevens Wohangara (The Forest Trust - TFT), Setiadi (PT. Wira Karya Sakti), Sugeng, Haidir, Khalil, Effendi (Lurah Senyerang), dan seluruh warga Kelurahan Senyerang, Kabupaten Tanjung Jabung Barat, Provinsi Jambi.

\section{Rujukan}

Botes, J. 2003. Conflict Transformation: A Debate over Semantics or a Crucial Shift in the Theory and Practice of Peace and Conflict Studies, International Journal of Peace Studies 8(2):1-27.

Crawford, D. dan Bodine, R. 1996. Conflict Resolution Education: A Guide to Implementing Programs in Schools, Youth-Serving Organizations, and Community and Juvenile Justice. Department of Education, Office of Juvenile Justice and Delinquency Prevention, New York: Office of Juvenile Justice and Delinquency Prevention.

Dhiaulhaq, A., Gritten, D., De Bruyn, T., Yasmi, Y., Zazali, A. dan M. Silalahi. 2014. Transforming conflicts in plantations through mediation: Lessons and experiences from Sumatra, Indonesia, Forest Policy and Economics, 41, pp. 22-30.

Dhiaulhaq, A., De Bruyn, T. dan Gritten, D. 2015. The use and effectiveness of mediation in forest and land conflict transformation in Southeast Asia: Case studies from Cambodia, Indonesia and Thailand, Environmental Science \& Policy, 45, pp. 132-45.

Engel, A. dan B. Korf. 2005. Negotiation and Mediation Techniques for Natural Resource Management. Roma: FAO.

Food and Agriculture Organization. 2010. Global Forest Resources Assessment 2010: Main report, FAO Forestry Paper 163, Food and Agriculture Organization, Roma.

Fisher, S., Abdi, D.K., Ludin, J., Smith, R., Williams, S. dan Williams, S. 2001. Mengelola konflik: keterampilan dan strategi untuk bertindak. The British Council, Indonesia.

Forest Watch Indonesia. 2014. Pengabaian Kelestarian Hutan Alam dan Gambut, serta Faktor Pemicu Konflik Lahan yang Berkelanjutan: Studi Kasus Ekspansi Industri Pulp and Paper di Provinsi Sumatera Selatan, Riau dan Jambi. Lembar Fakta FWI 2014 http://fwi.or.id/wp-content/uploads/2014/09/LembarFakta_Ekspansi-Industri-Pulp-and-Paper_2014_lowres.pdf . Diakses 21 November 2014.

Kementerian Kehutanan. 2014. Kebijakan Pembangunanan Hutan Tanaman Industri: Presentasi. Jakarta: Direktorat Jenderal Bina Usaha Kehutanan, Kementerian Kehutanan.

Komisi Pembaruan Agraria. 2013. Laporan Akhir Tahun 2013 Konsorsium Pembaruan Agraria "Warisan Buruk Masalah Agraria Di bawah Kekuasaan SBY". Jakarta: Komisi Pembaruan Agraria.

Komisi Pembaruan Agraria. 2012. Laporan Akhir Tahun 2012 Konsorsium Pembaruan Agraria "Terkuburnya Keadilan Agraria Bagi Rakyat Melalui Reforma Agraria". Jakarta: Komisi Pembaruan Agraria.

Kompas. 2012, 31 Maret. Sejarah itu kembali berulang di Senyerang. Harian Kompas. http://tekno.kompas.com/ $\mathrm{read} / 2012 / 03 / 31 / 03071270 / \mathrm{sejarah.itu.kembali.berulang.}$ di.senyerang

Metro Jambi. 2012, 1 Juni. Penyelesaian Konflik Senyerang, Gunakan Pendekatan Extra Ordinary. http://www.metrojambi. com/v1/home/wawancara/4263-penyelesaian-konfliksenyerang-gunakan-pendekatan-extra-ordinary.html

Moore, C.W. 2003. The mediation process - practical strategies for resolving conflict. San Francisco, California, AS, Jossey Bass Wiley. 
Rahmadi, T. 2010. Mediasi: Penyelesaian Sengketa Melalui Pendekatan Mufakat. Jakarta: PT Rajagrafindo Persada.

Sirait, M., Muhshi, M. A., dan Suwito. 2012, Oktober. Pengalaman mediasi konflik antara PT. Wira Karya Sakti dengan masyarakat kelurahan Senyerang Kabupaten Tanjung Jabung Barat Jambi. Warta Tenure (10) pp. 19-24.

Syukur, F.A. dan Bagshaw, D.M. 2013. Court-annexed mediation in Indonesia: does culture matter? Conflict Resolutution Quarterly, 30, 369-390.

Usman, M. 2012. Hasil liputan, Senyerang melawan Sinar Mas. Dalam A. M. Asfar, A. Wahyuni, A. A. Ghofur, A. Chusna, A. Prawitasari, Kusti'ah, dkk., Menggedor Pintu, Mendobrak Sekat
Informasi. Pengalaman Jurnalis Memohon Informasi Publik (pp. 142-151). Jakarta: Aliansi Jurnalis Independen (AJI).

Vestergaard, B., Helvard, E. dan Sorensen, A.R. 2011. Conflict Resolution - Working With Conflicts. Frederiksberg, Denmark: Danish Centre for Conflict Resolution.

Wulan, Y.C., Yasmi, Y., Purba, C. dan Wollenberg, E. 2004. Analisa konflik sektor kehutanan di Indonesia 1997-2003. Bogor, Indonesia: Center for International Forestry Research (CIFOR). Yasmi, Y., Kelley, L. dan Enters, T. 2010. Conflict Over Forests and Land in Asia: Impacts, Causes, and Management. Bangkok: RECOFTC.

\begin{tabular}{l|ll|} 
PROGRAM & Penelitian ini dilaksanakan oleh CIFOR sebagai bagian dari Program Penelitian CGIAR pada Hutan, Pohon dan \\
PENELITIAN PADA & Wanatani (CRP-FTA). Program kolaboratif ini bertujuan untuk meningkatkan pengelolaan dan pemanfaatan \\
Hutan, Pohon dan & hutan, wanatani, dan sumber daya genetis pohon yang mencakup lanskap dari hutan sampai ke lahan budidaya. \\
Wanatani & $\begin{array}{l}\text { CIFOR memimpin CRP-FTA melalui kemitraan dengan Bioversity International, CATIE, CIRAD, International Center } \\
\text { for Tropical Agriculture dan World Agroforestry Centre. }\end{array}$
\end{tabular}

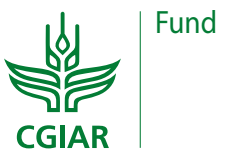

